\title{
Is External Debt a Boon or a Curse? Empirical Evidence from South Asian Countries
}

\author{
MUHAMMAD REEHAN HAMEED \\ Assistant Professor of Economics, Department of Economics, \\ Government College of Science, Wahdat Road, Lahore, Punjab, Pakistan. \\ Email: reehanhameed@yahoo.com \\ Tel: +923456368268 \\ MAJID ALI \\ Assistant Professor of Economics, Department of Economics, \\ PMAS-Arid Agriculture University, Rawalpindi, Punjab, Pakistan. \\ Email: majid.uos@gmail.com \\ Tel: +923003969173 \\ HAFSAH BATOOL \\ Lecturer in Economics, Department of Economics, \\ Lahore College for Women University, Lahore, Punjab, Pakistan. \\ Email: batooleconomists@gmail.com \\ Tel: +923218026888
}

\begin{abstract}
Over the years, the South Asian countries were facing the dilemma of twin's deficits because they had failed to generate sufficient revenues to finance their budget. Consequently, they were continuously relying on both domestic and external debt to bridge these deficits which had put a severe implication on their economic growth. Their financial position continued to deteriorate and undermined all the efforts of the governments made to stimulate economic growth. The governments in these countries failed to generate enough revenues through internal sources. Therefore, the deficits were normally fiancé through external sources. The paper examined whether the external debt was a blessing or course to the economic growth of South Asian countries i.e. Bangladesh, Bhutan, India, Maldives, Nepal, Pakistan, and Sri Lanka. For this purpose 30 years of panel data of these countries from 1990 to 2019 had been taken. Fixed effect model and Panel Autoregressive Distributive Lag (ARDL) Approach had been applied to examine the short-run and long-run association among the variables. The natural log of GDP per capita was used as a proxy for economic growth. The other variables were external debt, initial GDP, foreign direct investment, trade openness, investment, and secondary school investment rate. The outcomes of the study indicated that that external debt had a negative impact on economic growth both in the short-run and long-run. This revealed that external debt had not been utilized effectively and productively. The study suggested that effort would be made to manage the external debt and reduced the twin's deficits to minimize the harmful impact of external debt on the economy.
\end{abstract}

Keywords: South Asian, External Debt, ARDL, Fixed Effect Model, Economic Growth.

\section{Introduction}

One of the biggest challenges which the South Asian countries are facing at the beginning of the $21^{\text {st }}$ century is the mounting external deficit which has severely affected the growth performance of these countries. Developing countries depend on external debt to finance its projects because of its low savings 
and low income (Moh. and Jaradat, 2019). External debt accumulation has become a common phenomenon as far as developing countries are concerned. Due to mounting budget deficits, low saving potential, limited taxable capacity, and ever-increasing government expenditures they are continuously relying on both domestic and external debt.

The government can finance its budget and development needs through borrowings or taxing on productivity. However, in developing countries due to low taxable capacity, the government revenues always remain short of its expenditures. If the government increases the taxes to minimize the gap between revenue and expenditures, it will distort the structure of relative prices, severely affects the purchasing power of the people, increase poverty, and creates disparities in the distribution of income which undermines growth. However, borrowings are necessary to finance public expenditures, enhance social welfare and stimulate economic growth.

Most economists and policymakers give considerable attention to external debt as compared to domestic debt. They argued that increasing resources through internal borrowings to finance budget deficits or to wipe up 'monetary liquidity' having so many costs and benefits for the economy which are very difficult to assess. The only justification given in favor of domestic debt in poor countries is that it is easily accessible, stir up the domestic financial market, and provide shelter to countries from adverse external shocks, and minimize 'foreign exchange' risks (Del \& Piero, 2003; Aizenman et al., 2007; Kumhof \& Tanner, 2005).

The most important apprehension regarding domestic debt is that it crowds out private investment. Domestic borrowings on the part of the government made through domestic private savings are mostly used by the private lenders for investment. It put constraints on the availability of loans for the private borrowers which crowds out private investment, reduced capital accumulation, and discourage economic growth (Diamond, 1965). Domestic borrowings are perhaps considered more expensive as compared to external concessional loans (Burguet \& Ruiz, 1998). The increased payments of domestic interest rate swallow a major portion of the government development budget which slows down economic growth.

Due to the above-mentioned problems, the government fails to generate enough revenues through internal sources which necessitated the need to accumulate resources through external borrowings to finance expenditures and sustain the growth rate of the economy. However, as argued by Chowdhury, 2001 that"a reasonable level of borrowings are likely to enhance economic growth, through capital accumulation and productivity growth". As in the initial level of development, most of the countries have limited capital stock and reduced investment opportunities. Foreign borrowings if utilized productively are very much helpful in bringing macroeconomic stability (Burnside, 2000). External borrowings increase the inflow of capital, stimulates domestic savings, investment, and growth in the economy. However, external debt has a dark side also.

The adverse effects of external debt arise through the debt overhang effect which postulates that if the debt level of a country exceeds to country's repayment ability than expected debt servicing increases and some of the returns of investing in the domestic economy are taken away by the existing foreign creditors which discourage both domestic and foreign investment (Krugman, 1988; Sachs, 1990; Karagol, 2002). The other channel through which external debt affects growth is the crowding out effect. If a major share of foreign exchange earned use to service debt, a very small amount of capital will be available for investment and growth. The shortage of capital which is the resultant factor of debt servicing cost of public debt increases domestic interest rate which crowds out private investment and deters economic growth in the country (Karagol, 2002; Alejandro, 1981).

Numerous factors led to a huge accumulation of external debt in South Asian countries. One of the prime factors was the increase in petroleum prices by OPEC countries in 1973/74 which has worsened the current account position by increasing the import bill of these countries and compel them to borrow heavily to bridge their account deficits. On the other hand, defective economic policies, improper utilization of 
borrowed funds, mismanagement, political instability, corruption, deteriorating law and order conditions are some of the factors which are responsible for their huge stock of external debt in these countries. Therefore, it is pertinent that a throw investigation has been made to investigate the impact of growing external debt on South Asian economies.

\section{Overview of Public Debt of South Asian Countries}

The external debt statistics of South Asian countries given in table 1 are showing that it is continuously increasing for the last three decades in these countries. The effect of increasing debt burdens on economic growth is, therefore essential.

Table 1: The Trend of External Debt (ED)

(US Billion \$)

\begin{tabular}{|cccccccc|}
\hline Year & Bangladesh & Bhutan & India & Maldives & Nepal & Pakistan & Sri lanka \\
\hline $\mathbf{1 9 9 0}$ & 10.61 & 0.08 & 83.80 & 1.63 & 0.06 & 15.20 & 5.87 \\
$\mathbf{1 9 9 5}$ & 16.77 & 0.11 & 93.73 & 2.41 & 0.15 & 21.74 & 8.40 \\
$\mathbf{2 0 0 0}$ & 16.21 & 0.12 & 96.39 & 2.88 & 0.20 & 28.46 & 9.25 \\
$\mathbf{2 0 0 5}$ & 19.29 & 0.25 & 134.00 & 3.19 & 0.36 & 34.18 & 11.30 \\
$\mathbf{2 0 1 0}$ & 20.34 & 0.84 & 260.94 & 3.79 & 0.92 & 51.08 & 21.68 \\
$\mathbf{2 0 1 5}$ & 23.90 & 1.50 & 474.68 & 4.14 & 0.97 & 50.42 & 43.93 \\
$\mathbf{2 0 1 6}$ & 26.31 & 1.90 & 485.83 & 4.25 & 1.16 & 57.76 & 46.61 \\
$\mathbf{2 0 1 7}$ & 28.57 & 2.26 & 495.70 & 5.95 & 1.19 & 62.13 & 47.80 \\
$\mathbf{2 0 1 8}$ & 33.51 & 2.67 & 529.70 & 8.09 & 1.30 & 95.10 & 53.50 \\
$\mathbf{2 0 1 9}$ & 37.80 & 2.72 & 543.00 & 8.90 & 2.43 & 113.80 & 55.91 \\
\hline
\end{tabular}

Source: International Debt Statistics, various databases.

The main objectives of the study are

- To investigate whether external debt stimulates or deters economic growth in South Asian Countries.

- $\quad$ To suggest some policy recommendations

\section{Research Question of the Study}

The study is designed to answer the following research question.

- Does external debt is a boon or a curse on economic growth for South Asian countries?

\section{Literature Review}

Cunningham (1993) examined the effect of increasing public indebtedness on the growth performance of 16 HIPC. For this purpose, eight years of data from 1971-1979 had been taken. The outcomes of the study indicated that a heavy debt burden in HIPC had affected growth negatively. Fosu (1996) investigated the impact of debt on economic performance. For this purpose, 46-year data of Sub Saharan Africa (SSA) from 1970-1986 had been used. The results exhibited a negative relationship between debt and growth in SSA countries. Iyoha and Milton (1999) explored the link between foreign debt on the economic growth (EG) of SSA from 1970-1994. The result exhibited that high and growing debt decreased investment through crowding out effect. The study suggested to reduceg debt stock to stimulate growth and investment in SSA countries.Ward et al. (2002) examined the impact of external debt on EG. The sample contained 
93developing countries. For this purpose, 29 years of data of these countries starting from 1969-1998 had been used. The results obtained revealed that along with doubling the debt level, the growth rate would reduce between 50 to 100 percent.

Maghyereh (2003) analyzed the impact of foreign indebtedness on EG in Jordan. For this purpose, 31 years of data from 1970 to 2000 had been used. The results showed that up to 53\% of GDP debt had affected growth positively. But beyond that level, the effect became negative. Moreover, a $1 \%$ raised in investment to GDP ratio increased GDP by $0.37 \%$.

Mohamed (2005) examined the debt and growth relationship in Sudan. For this purpose, the 23 years of data from 1978-2001 had been used. The results exhibited that foreign debt and EG were negatively related

to each other. Bakar and Hassan (2008) explored how debt affected growth in Malaysia. For this purpose of 36 years of data of the Malaysian economy from 1970 to 2005 had been used. The results revealed that foreign debt and economic growth had been negatively associated with each other in Malaysia. As in the long run, a $1 \%$ rise in external debt increased economic growth by $1.29 \%$.

Ayadi and Ayadi (2008) analyzed the debt and growth relationship. For this purpose, 13 years of data of Nigeria and South African economies from 1994-2007 had been used. The study results revealed that debt and growth were negatively related to each other in Nigeria and South African countries. Paudel and Perera (2009) examined the relationship among foreign debt and some of the other variables on the growth of Sri Lanka. For this purpose, 56 years of data from 1950-2006 had been used. The results indicated that external debt had stimulated growth in Sri Lanka in the long run.

Reinhart and Rogoff (2010) found out the association among growing public indebtedness, growth performance, and inflation. They used the data of 44 developed countries. The results indicated that after a specific level of debt to GDP ratio ( $90 \%$ and above), public indebtedness had affected growth negatively in developed countries. Amassoma (2011) examined the impact of foreign borrowings, internal borrowings on the growth of Nigeria. They used the data of 39 years between 1970 and 2009. From the results, it was evident that foreign borrowing negatively affected growth.

Sulaiman and Azeez (2012) analyzed the impact of foreign indebtedness on growth. For this purpose 40 years of data of the Nigerian economy from 1970 to 2010 had been taken. The results obtained revealed that foreign borrowings adversely affected growth in Nigeria. Baum et al. (2013) analyzed the relationship between public borrowings and growth in 12 euro area economies. For this purpose, 21 years of data from 1990 to 2010 had been used. The result obtained indicated that debt, in the short run, affected growth positively. The effect had decreased and become zero when the debt to GDP ratio reached around $67 \%$. Further, the results also revealed that the effect of debt became harmful when it increased to $95 \%$.

Lof and Malinen (2014) explored the link between external borrowings and the growth of 20 European economies. For this 20 years data from 1954 to 2008 and 1905 to 2008 had been used. The results obtained indicated that foreign indebtedness adversely affected growth. The study reported that the mounting debt burden was a big hindrance to economic growth. Baaziz et al. (2015) analyzed the impact of public borrowings on growth in South Africa (SA). For this purpose, 34 years of data from 1980 to 2014 had been used. The results indicated debt had asserted a negative impact on growth when the debt to GDP ratio increased to $31.37 \%$.

Serrao (2016) conducted research to see the connection between public loans and growth. For this purpose, 63 years data of advanced economies from 1946 to 2009 had been taken. The outcomes of the study indicated that public loans discouraged growth. As a $1 \%$ increase in debt to GDP ratio led to reduce growth by $1.13 \%$. Ijirshar et al. (2016) made a study to see the effect of foreign indebtedness on the growth of Nigeria. Time series data of 34 years from 1981 to 2014 had been used. The result obtained exhibited that 
foreign indebtedness and growth were negatively associated with each other. Nantwi and Erickson (2016) analyzed the association between debt and growth in Ghana. For this purpose, 42 years of data from 1970-2012 had been used. The result revealed that public debt positively stimulated growth. Jacobo and Jalile (2017) examined the effect of public indebtedness on growth in 16 Latin American countries. Time series of 55 years from 1960-2015 had been used. The results revealed that debt had a positive impact on growth. However, its effect was negligible when it was $64-71 \%$ of GDP.

Chiminya et al. (2018) investigated the impact of external borrowings on the growth of 37 SSA economies. For this purpose, 32 years of data from 1980-2012 had been used. The results showed that foreign borrowing had a negative effect on short-term and long-term economic growth. Shittu et al. (2018) explored the effect of external borrowings and corruption on the growth of 5 SSA economies. For this purpose, 25 years of data from 1990 to 2015 had been used. The outcomes showed that foreign borrowings had an adverse impact on growth. Abdelaziz et al. (2019) investigated the effect of foreign borrowings on investment and growth in 23 developing economies. For this purpose, panel data of 17 years from 2000 to 2017 had been taken. The result obtained revealed that foreign debt depressed growth and investment in both cases.

\section{Methodology and Model Specification}

The study has used the following methodologies to estimate the results

- Hausman Test

- $\quad$ Fixed Effect Model

- Panel Unit Root Tests

- Panel Autoregressive Distributive Lag (ARDL) Approach

The model used in the study relates economic growth to the external debt burden. The general form of the model can be written as

The Model

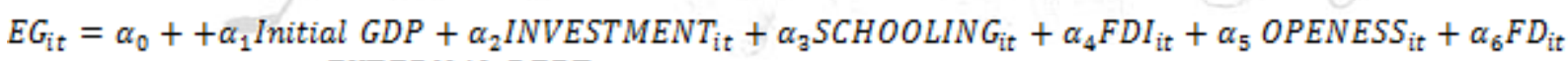
$+\alpha_{7}$ EXTERNAL DEBT it $+\mu_{\text {it }}$

Where

$\alpha_{0}=$ Intercept

$=$ Cross section dimensions.

$t=$ Time-series dimensions.

Growth $_{\mathbf{i t}}=$ Real GDP Per Capita measured as the natural log of current minus Previous year Real GDP per capita, i.e. $\log \left(\mathrm{GDPPC}_{\mathrm{t}}-\mathrm{GDPPC}_{\mathrm{t}-1}\right)$

Initial $_{\mathbf{G D P}_{\mathrm{it}}}=$ Initial level of income measured as twenty years lagged value of the log of real GDP per capita

Investment ${ }_{\text {it }}=$ Investment as measured by gross fixed capital formation as a share of GDP

Schooling $_{i t}=$ Secondary school enrollment rate

$\mathbf{F D I}_{\mathbf{i t}}=$ Foreign direct investment as a share of GDP

Openness $_{\text {it }}=$ Trade openness as a share of GDP measured as (Exports + Imports)/GDP

$\mathbf{F D}_{\text {it }}=$ Financial development measured as a credit to the private sector as a share of GDP

External debt $_{i t}=$ Public debt to GDP ratio 


\section{Data Source}

To examine whether external debt stimulates or deters economic growth in of South Asian Countries. The 30 years panel data from 1990 to 2019 have been taken. Data has been collected from World Development Indicators (WDI), International Monetary Fund (IMF), and International Debt Statistics various data bases.

\section{Results Discussion and Analysis}

\section{Hausman Test Results}

The Hausman test results of the Model given in table 2 indicate that the FEM is better. The null hypothesis is rejected at a $1 \%$ level of significance.

Table 2: Hausman Test Results

Null Hypotheses is Random Effect Model is Appropriate

\begin{tabular}{|ccc|}
\hline Chi-Sq. Statistic & Chi-Sq. d.f. & Prob. \\
\hline 19.994132 & 7 & $0.0056^{*}$ \\
\hline
\end{tabular}

*** Null Hypothesis rejected at $1 \%$.

\section{Fixed Effect Model (FEM) Results}

The FEM results of the Model presented in table 3 indicate the coefficient of initial GDP has a negative sign and significant, which shows the convergence among countries. Investment stimulates economic growth positively. One percent increase in investment leads to increase economic growth by 0.29 percent. Investment causes domestic production to increase, which raises the level of income and employment in the country, leading to boost economic growth. According to Keynesian points of view, public investment is an essential instrument of the government to increase the output up to some particular level. Investment leads to an increase in the aggregate supply by enhancing the level of domestic output, income, and employment.

Table 3: Fixed Effect Model Results Dependent Variable: Economic Growth (EG)

\begin{tabular}{|c|c|c|c|c|}
\hline Variable & Coefficient & Std. Error & t-Statistic & Prob. \\
\hline Initial GDP & -1.102903 & 0.253666 & $-4.347862 * * *$ & 0.0000 \\
\hline Investment & 0.292183 & 0.129606 & $-2.254398 * *$ & 0.0254 \\
\hline Schooling & 0.005243 & 0.001988 & $2.638137 * * * *$ & 0.0091 \\
\hline FDI & 1.463573 & 1.614266 & 0.906649 & 0.3659 \\
\hline Openess & 0.000532 & 0.000202 & $2.638650^{* * *}$ & 0.0091 \\
\hline FD & 1.289387 & 0.194359 & $6.634035^{* * *}$ & 0.0000 \\
\hline External Debt & -0.323898 & 0.152500 & $-2.123922 * *$ & 0.0351 \\
\hline $\mathbf{C}$ & 4.252895 & 0.636063 & $6.686278^{* * *}$ & 0.0000 \\
\hline \multicolumn{5}{|c|}{ Number of Observations $=184$} \\
\hline
\end{tabular}

The aggregate demand also increases, which further enhances the level of income, employment through the multiplier effect (Rabnawaz et al., 2015). The other variables like schooling, FDI, openness, and financial development stimulate economic growth. External debt has a negative and significant relationship with economic growth. One percent increase in external debt to GDP ratio depresses economic growth 0.32 percent. This is in accordance with the liquidity constraints and debt overhang hypothesis as described by 
Krugman, (1988), and Cohen, (1995) which postulate that if external debt increases than the country's repayment capacity the expected debt servicing increases, and some of the returns of investing in the domestic economy in the form of increased output are taken away by the existing foreign creditor which discourages investment and economic growth. The debt servicing is like an expensive tax bill that the countries have to pay from their future income. Borrowed funds, if utilized for consumption purposes instead of productive investment, fail to generate future income which turns into a debt burden and asserts a negative impact on economic growth. Moreover, a high level of debt enhances government domestic borrowings, increases the domestic interest rate, which makes the cost of borrowings more expensive and crowds out private investment, consumption, and dampens economic growth.

Moreover, inefficient and poor management of borrowed funds in these countries have a negative effect on economic growth and financial stability. This negative relationship between external debt and growth is supported by many studies i.e. Van, (1983 \& 1989); Aizenman \& Marion, (2011); Buite \& Patel, (1992); Hafer \& Hein, (1988); Aiyagari \& McGrattan, (1988).

Panel Unit Root Test Results

Table 4: Panel Unit Root Test Results

\begin{tabular}{|c|c|c|c|c|c|c|c|c|}
\hline \multirow{3}{*}{ Variables } & \multicolumn{4}{|c|}{$\begin{array}{c}\text { ADF - Fisher Chi-square } \\
\text { \& } \\
\text { PP - Fisher Chi-square }\end{array}$} & \multicolumn{4}{|c|}{$\begin{array}{c}\text { Levin, Lin \& Chu Unit Root Test } \\
\text { \& } \\
\text { I'm, Pesaran \& Shin Unit Root Test }\end{array}$} \\
\hline & \multicolumn{2}{|c|}{$\mathbf{I}(\mathbf{0})$} & \multicolumn{2}{|c|}{$\mathbf{I}(\mathbf{1})$} & \multicolumn{2}{|c|}{$\mathbf{I}(\mathbf{0})$} & \multicolumn{2}{|c|}{$\mathbf{I}(\mathbf{1})$} \\
\hline & Intercept & $\begin{array}{l}\text { Intercept } \\
\& \text { Trend }\end{array}$ & Intercept & $\begin{array}{l}\text { Intercept \& } \\
\text { Trend }\end{array}$ & Intercept & $\begin{array}{l}\text { Intercept } \\
\& \text { Trend }\end{array}$ & Intercept & $\begin{array}{c}\text { Intercept \& } \\
\text { Trend }\end{array}$ \\
\hline \multirow{3}{*}{ EG } & $\begin{array}{c}15.3408 \\
(0.3553)\end{array}$ & $\begin{array}{c}34.1173 * \\
(0.0020)\end{array}$ & $\begin{array}{c}101.951 \text { ** } \\
(0.0000)\end{array}$ & $\begin{array}{c}80.6862 * * \\
(0.0000)\end{array}$ & $\begin{array}{c}-0.42124 \\
(0.3368)\end{array}$ & $\begin{array}{c}-0.61898 \\
(0.2680)\end{array}$ & $\begin{array}{l}-9.24543^{* *} \\
(0.0000)^{* *}\end{array}$ & $\begin{array}{c}-7.21780 * * \\
(0.0000)\end{array}$ \\
\hline & $45.4848 *$ & $89.7759 *$ & $285.529 * *$ & $1280.84 * *$ & -0.57002 & $2.24759 *$ & -9.99173 & $-5.55664 * *$ \\
\hline & $(0.0000)$ & $(0.0000)$ & $(0.0000)$ & $(0.0000)$ & $(0.2843)$ & $(0.0123)$ & $(0.0000)$ & $(0.0000)$ \\
\hline \multirow{4}{*}{ Initial GDP } & 2.25745 & $28.1475^{*}$ & $64.7321 * *$ & $98.8194 * *$ & 3.97954 & $-0.89090 *$ & $-10.9359 * *$ & $-10.0583^{* *}$ \\
\hline & $(0.9998)$ & $(0.0136)$ & $(0.0000)$ & $(0.0000)$ & $(1.000)$ & $(0.1865)$ & $(0.0000)$ & $(0.0000)$ \\
\hline & 3.27814 & 25.7654 & $135.134 * *$ & $375.271 * *$ & 4.97456 & -0.83238 & $-9.13817 * *$ & $-9.02429 * *$ \\
\hline & $(0.9985)$ & $(0.0277)$ & $(0.0000)$ & $(0.0000)$ & $(1.0000)$ & $(0.2026)$ & $(0.0000)$ & $(0.0000)$ \\
\hline \multirow{4}{*}{ Investment } & 14.3569 & 10.7768 & $58.0380 * *$ & $41.8792 * *$ & -0.93251 & 0.19471 & $-3.36381 * *$ & $-1.82436 * *$ \\
\hline & $(0.4235)$ & $(0.7035)$ & $(0.0000)$ & $(0.0001)$ & $(0.1755)$ & $(0.5772)$ & (0.0004) & $(0.0340)$ \\
\hline & 11.0762 & 6.07604 & $98.0147 * *$ & $80.9612 * *$ & 0.10167 & -0.84977 & $-5.63140 * *$ & $-4.15617 * *$ \\
\hline & $(0.6800)$ & $(0.9645)$ & $(0.0000)$ & $(0.0000)$ & (0.5406) & (0.1977) & $(0.0000)$ & $(0.0000)$ \\
\hline \multirow{4}{*}{ Schooling } & 8.48107 & 18.5705 & $46.8601 * *$ & $35.9731 * *$ & -0.61701 & -0.19714 & $-2.41953 * *$ & $-1.63831 * *$ \\
\hline & $(0.8628)$ & $(0.1820)$ & $(0.0000)$ & $(0.0011)$ & $(0.2686)$ & $(0.4219)$ & $(0.0078)$ & $(0.0507)$ \\
\hline & 7.17715 & $43.3847^{*}$ & $79.6024 * *$ & $311.025 * *$ & 2.11146 & 0.34865 & $-4.13785^{* *}$ & $-1.16291 * *$ \\
\hline & $(0.9277)$ & $(0.0001)$ & $(0.00000$ & $(0.0000)$ & $(0.9826)$ & $(0.6363)$ & $(0.0000)$ & $(0.1224)$ \\
\hline \multirow{4}{*}{ FDI } & $39.9213 *$ & $33.9051 *$ & $106.797 * *$ & $83.0056 * *$ & $-2.12924 *$ & $-1.43917 *$ & $-6.86023 * *$ & $-5.68908 * *$ \\
\hline & $(0.0003)$ & $(0.0021)$ & $(0.0000)$ & $(0.0000)$ & $(0.0166)$ & $(0.0751)$ & $(0.0000)$ & $(0.0000)$ \\
\hline & $46.1231 *$ & 47.8958 & $177.022 * *$ & $550.030 * *$ & $-3.12094 *$ & $-.53434 *$ & $-9.83286 * *$ & $-5.24242 * *$ \\
\hline & $(0.0000)$ & $(0.0000)$ & $(0.0000)$ & $(0.0000)$ & $(0.0009)$ & $(0.0002)$ & $(0.0000)$ & $(0.0000)$ \\
\hline \multirow{4}{*}{ Openess } & 12.5340 & 17.6877 & $73.9535 * *$ & $55.9845 * *$ & 0.68512 & -0.49804 & $-7.92743 * *$ & $-7.00138 * *$ \\
\hline & $(0.5635)$ & $(0.2214)$ & $(0.0000)$ & $(0.0000)$ & $(0.7534)$ & $(0.3092)$ & $(0.0000)$ & $(0.0000)$ \\
\hline & 12.4420 & 10.1667 & $109.979 * *$ & $98.2954 * *$ & 0.7559 & -0.07977 & $-7.01743 * *$ & $-4.80455^{* *}$ \\
\hline & $(0.5709)$ & $(0.7499)$ & $(0.0000)$ & $(0.0000)$ & $(0.7751)$ & $(0.4642)$ & $(0.0000)$ & $(0.0000)$ \\
\hline \multirow{4}{*}{ FD } & $39.9213 *$ & $33.9051 *$ & $106.797 * *$ & $83.0056 * *$ & -2.12924 & $-1.43917 *$ & $-6.86023 * *$ & $-5.68908 * *$ \\
\hline & $(0.0003)$ & $(0.0021)$ & $(0.0000)$ & $(0.0000)$ & $(0.0166)$ & $(0.0751)$ & $(0.0000)$ & $(0.0000)$ \\
\hline & $46.1231 *$ & $47.8958^{*}$ & $177.022 * *$ & $550.030 * *$ & $-3.12094 *$ & $-3.53434 *$ & $-9.83286 * *$ & $-8.18007 * *$ \\
\hline & $(0.0000)$ & $(0.0000)$ & $(0.0000)$ & $(0.0000)$ & $(0.0009)$ & $(0.0002)$ & $(0.0000)$ & $(0.0000)$ \\
\hline \multirow{4}{*}{$\begin{array}{c}\text { External } \\
\text { Debt }\end{array}$} & 8.80590 & 13.7245 & $79.1204 * *$ & $65.9660 * *$ & 1.85584 & -015702 & $-6.47243 * *$ & $-6.76411 * *$ \\
\hline & $(0.8433)$ & $(0.4704)$ & $(0.00000$ & $(0.0000)$ & $(0.9683)$ & $(0.4376)$ & $(0.0000)$ & $(0.0000)$ \\
\hline & 7.45030 & 17.1516 & $124.110 * *$ & $355.193 * *$ & 2.22754 & -0.00833 & $-7.38805^{* *}$ & $-6.60247 * *$ \\
\hline & $(0.9160)$ & $(0.2482)$ & $(0.0000)$ & $(0.0000)$ & $(0.9870)$ & $(0.5033)$ & $(0.0000)$ & $(0.0000)$ \\
\hline
\end{tabular}

Values in Parentheses are p-values. * Stationary at a level. ** At first difference. 
The panel unit root test results presented in Table 4 indicate that Economic growth, Initial GDP Schooling, FDI, and FD are stationary at the order I(0), and other variables i.e. Investment, openness, and External debt are at the order I(1). So, we can use the Panel ARLD approach to estimate the long-run association among the variables.

\section{Panel Autoregressive Distributive Lag (ARDL) Model or Pooled Mean Group (PMG) Results}

The Panel ARDL results presented in table 5 reveal that the coefficient of initial GDP is negative and significant, which indicates the convergence among countries. Investment positively influences economic growth. One percent increase in investment brings a 0.32 percent increase in economic growth. Schooling is positively associated with economic growth in the long-run. FDI is positively linked with economic growth. Openness indicator exhibits a positive relation with economic growth. Financial development influenced growth positively. External debt is adversely and significantly related to economic growth in LR. Debt, if not adequately utilized having a disastrous effect on EG. The short-run result of Panel ARDL indicates that the ECT is negative and significant, which indicates the speed of adjustment of the model towards the equilibrium. The external debt has a negative and significant relation with EG in the short run.

Table 5: Panel ARDL Results

Dependent Variable Economic Growth (EG)

\begin{tabular}{|c|c|c|c|c|}
\hline Variable & Coefficient & Std. Error & t-Statistic & Prob. \\
\hline \multicolumn{5}{|c|}{ Long Run Equation } \\
\hline Initial GDP & -1.432065 & 0.230277 & $-6.218879 * * *$ & 0.0000 \\
\hline Investment & 0.327160 & 0.141451 & $-2.312885^{* *}$ & 0.0225 \\
\hline schooling & 0.010359 & 0.001942 & $5.334335 * * *$ & 0.0000 \\
\hline FDI & 3.246883 & 2.054947 & 1.580033 & 0.1169 \\
\hline Openess & 0.000702 & 0.000244 & $2.876830 * * *$ & 0.0048 \\
\hline FD & 1.054183 & 0.176517 & $5.972121 * * *$ & 0.0000 \\
\hline External Debt & -0.556657 & 0.156902 & $-3.547804 * * *$ & 0.0006 \\
\hline \multicolumn{5}{|c|}{ Short Run Equation } \\
\hline COINTEQ01 & -0.939240 & 0.150462 & $-6.242384 * * *$ & 0.0000 \\
\hline D(Initial GDP) & 1.557662 & 1.498687 & 1.039351 & 0.3008 \\
\hline D(Investment) & 0.588151 & 1.038369 & 0.566418 & 0.5722 \\
\hline D(Schooling) & 0.000480 & 0.020642 & 0.023235 & 0.9815 \\
\hline D(FDI) & 2.436979 & 3.369882 & 0.723165 & 0.4711 \\
\hline D(Openess) & 0.553818 & 0.308169 & $1.797122 *$ & 0.0750 \\
\hline $\mathbf{D}(\mathbf{F D})$ & -1.331073 & 0.545715 & $-2.439137 * * *$ & 0.0163 \\
\hline D(External Debt) & -0.368504 & 0.0911432 & $-04.04313 * * *$ & 0.0067 \\
\hline C & 4.633892 & 0.698289 & $6.636063 * * *$ & 0.0000 \\
\hline
\end{tabular}

$* * *$ Significant at $1 \%$.** at $5 \%$.* at $10 \%$.

\section{Conclusion}

The main focus of the study is to investigate whether external debt stimulates or foster economic growth in South Asian countries from 1990 to 2019. Hausman test, Fixed effect model and Panel ARDL techniques are used to examine the short-run and long-run relationship among the variables. The results obtained indicate that external debt has a significant negative effect on economic growth both in the short run and long run. The negative impact of external debt on economic growth confirms the existence of debt overhang and liquidity constraints hypothesis in South Asian countries. Debts overhang theory postulates that external debt discourages domestic investment. Some of the returns of increase in domestic output are taken away by the existing foreign creditors in terms of debt repayment and its servicing charges. While 
because of the huge payment of debt the shortage of resources occur this causes the domestic interest rate to increase that crowds out private investment and discourages growth. The other variable investment, schooling, foreign direct investment, trade openness, and financial development stimulate growth in the long run.

\section{Policy Recommendations}

Based on the findings, the study recommends that the government should not rely heavily on external debt as it harms economic growth. The government should ensure that the projects financed through external debt must generate so much income that the country will be able to repay the principal amount along with its servicing charges. A viable monitoring system is necessary which guarantees the productive and optimal utilization of borrowed resources. Efforts will be made to reduce budget deficits and trade deficits so that the reliance on the external debt will come down.

\section{References}

Abdelaziz, H., Rim, B., \& Majdi, K. (2019). External Debt, Investment, and Economic Growth. Journal of Economic Integration, 34(4), 725-745.

Aiyagari, S. R., \& McGrattan, E. R. (1998). The Optimum Quantity of Debt. Journal of Monetary Economics, 42(3), 447-469.

Aizenman, J., \& Marion, N. (2011). Using Inflation to Erode the US Public Debt. Journal of Macroeconomics, 33(4), 524-541.

Aizenman, J., Pinto, B., \& Radziwill, A. (2007). Sources for Financing Domestic Capital-Is Foreign Saving a Viable Option for Developing Countries?. Journal of International Money and Finance, 26(5), 682-702.

Alejandro, D. (1981). Carlos:Southern Cone Stabilization Plans en William Cline y Sidney Weintraub (eds.): Economic Stabilization in Developing Countries. The Brookings Institution, Washington, oe.

Amassoma, D. (2011). External Debt, Internal Debt and Economic Growth Bound in Nigeria Using A Causality Approach. Current Research Journal of Social Sciences, 3(4), 320-325.

Ayadi, F. S., \& Ayadi, F. O. (2008). The Impact of External Debt on Economic Growth: A Comparative Study of Nigeria and South Africa. Journal of Sustainable Development in Africa, 10(3), 234-264.

Baaziz, Y., Guesmi, K., Heller, D., \& Lahiani, A. (2015). Does Public Debt Matter For Economic Growth?: Evidence From South Africa. Journal of Applied Business Research, 31(6), 2187-2196.

Bakar, A., \& Hassan, S. (2008). Empirical Evaluation on External Debt of Malaysia. International Business \& Economics Research Journal, 7(2), 95-108.

Baum, A., Checherita.W. C., Rother, P. (2013). Debt and Growth: New Evidence for the Euro Area. J. Int. Money Finance 32(C), 809-821.

Buiter, W. H., \& Patel, U. R. (1992). Debt, Deficits, and Inflation: An Application to the Public Finances of India. Journal of Public Economics, 47(2), 171-205.

Burguet, R., \& Fernández-Ruiz, J. (1998). Growth Through Taxes or Borrowing? A model of Development Traps with Public Capital. European Journal of Political Economy, 14(2), 327-344.

Burnside, C., \& Dollar, D. (2000). Aid, policies, and growth. American Economic Review, 90(4), 847-868.

Chiminya, A., Dunne, J. P., \& Nikolaidou, E. (2018). The Effects of External Debt on Growth in Sub Saharan Africa.School of Economics, the University of Cape Town (No. 2018-03).

Chowdhury, A. R. (2001). External Debt and Growth in Developing Countries: A Sensitivity and Causal Analysis. WIDER Discussion Paper No. 2001/95.

Cohen, D. (1995). Large External Debt and (Slow) Domestic Growth A Theoretical Analysis. Journal of Economic Dynamics and Control, 19(5-7), 1141-1163.

Cunningham, R. T. (1993). The Effects of Debt Burden on Economic Growth in Heavily Indebted Developing Nations. Journal of Economic Development, 18(1), 115-126.

Del V.C. Piero U., (2003), "The Development of Domestic Markets for Government Bonds," The Future of Capital Markets in Developing Countries. 
Diamond, P. A. (1965). National Debt in a Neoclassical Growth Model. The American Economic Review, 55(5), 1126-1150.

Fosu, A. K. (1996). The Impact of External Debt on Economic Growth in Sub-Saharan Africa. Journal of Economic Development, 21(1), 93-118.

Hafer, R. W., \& Hein, S. E. (1988). Further Evidence on the Relationship between Federal Government Debt and Inflation. Economic Inquiry, 26(2), 239-251.

Ijirshar, V. U., Joseph, F., \& Godoo, M. (2016). The Relationship between External Debt and Economic Growth in Nigeria. International Journal of Economics \& Management Sciences, 6(1), 1-5.

Iyoha and Milton (1999). External debt and Economic Growth in Sub-Saharan African Countries: An econometric study. AERC Research Paper 90 African Economic Research Consortium, Nairobi.

Jacobo, A. D., \& Jalile, I. R. (2017). The Impact of Government Debt on Economic Growth: An Overview for LatinAmerica (No. 28/2017). Università di Perugia, Dipartimento Economia.

Karagol, E. (2012). The Causality Analysis of External Debt Service and GNP: The Case of Turkey. Central Bank Review, 2(1), 39-64.

Karagol, E. (2012). The Causality Analysis of External Debt Service and GNP: The Case of Turkey. Central Bank Review, 2(1), 39-64.

Krugman, P. (1988).Financing vs. Forgiving a Debt Overhang . Journal of Development Economics, 29 , (253-268).

Kumhof, M., \& Tanner, E. (2005). “Government Debt: A Key Role in Financial Intermediation”. IMF working paper No. 05/5.

Lof, M., \& Malinen, T. (2014). Does Sovereign Debt Weaken Economic Growth? A panel VAR Analysis. Economics Letters, 122(3), 403-407.

Maghyereh, A. (2003). External Debt and Economic Growth in Jordan: the Threshold Effect. Economia Internazionale/International, Economics 56(3), 337-355.

Mohamed, M. A. A. (2005). The Impact of External Debts on Economic Growth: An Empirical Assessment of Sudan: 1978-2001. Eastern Africa Social Science Research Review, 21(2), 53-66.

Moh, K. A., \& Jaradat, M. S. (2019). Impact of external debt on economic growth in Jordan for the period (2010-2017). International Journal of Economics and Finance, 11(4), 104-113.

Nantwi, O., \& Erickson, V. (2016). Public Debt and Economic Growth in Ghana. African Development Review, 28(1), 116-126.

Paudel, R., \& Perera, N. (2009). Foreign Debt, Trade Openness, Labor Force and Economic Growth: Evidence from Sri Lanka. The IUP Journal of Applied Economics, 8(1), 57-64.

Rabnawaz, A., \& Sohail Jafar, R. (2015). Impact of Public Investment on Economic Growth. South Asia Journal of Multidisciplinary Studies (SAJMS), 8(1), 62-75.

Reinhart, C. M., and Rogoff, K. S. (2010). Growth in a Time of Debt (Digest Summary). American Economic Review, 100(2), 573-578.

Sachs, J. D. (1990). External debt, Structural Adjustment and Economic Growth. UNCTAD, International Monetary and Financial Issues for the, 9.

Serrao, A. (2016). Impact of Public Debt on Economic Growth in Advanced Economies. International Journal of Managerial Studies and Research (IJMSR) 4(2), 70-76.

Shittu, W. O., Hassan, S., \& Nawaz, M. A. (2018). The Nexus Between External Debt, Corruption and Economic Growth: evidence from five SSA countries. African Journal of Economic and Management Studies, 9(3), 319-334.

Sulaiman, L. A., \& Azeez, B. A. (2012). Effect of External Debt on Economic Growth of Nigeria. Journal of Economics and Sustainable Development, 3(8), 71-79.

Van Wijnbergen, S. (1983). Credit Policy, Inflation and Growth in a Financially Repressed Economy. Journal of Development Economics, 13(1-2), 45-65.

Van Wijnbergen, S. (1989). External Debt, Inflation, and the Public Sector: Toward Fiscal Policy for Sustainable Growth. The World Bank Economic Review, 3(3), 297-320.

Ward, H. P., Ricci, L., \& Pattillo, C. (2002). External Debt and Growth. External Debt and Growth, International Monetary Fund, 2(69), 1-47. 